\title{
THE ORIENTATION OF BIOLOGICAL NITROGEN TRANSFORMATION PROCESSES IN SOIL UNDER THE ORGANIC PRODUCTION OF AGRICULTURAL PRODUCTS
}

\author{
V. V. Volkohon, A. M. Moskalenko, S. B. Dimova, M. A. Zhurba, \\ K. I. Volkohon, L. M. Tokmakova, N. P. Shtanko, N. V. Lutsenko \\ Institute of Agricultural Microbiology and Agroindustrial Manufacture, NAAS \\ 97, Shevchenka str., Chernihiv, 14027, Ukraine; e-mail: rifam@ukrpost.ua
}

The paper covers the study of direct impact and after-effect of 40 t/ha of cattle manure on the orientation of nitrogen fixation and biological denitrification processes in the root zone of potatoes, spring barley, pea, and winter wheat plants in rotation in a stationary field experiments on leached black soil. Application of manure had significantly increased the nitrogen fixation activity, while promoting a high level of $\mathrm{N}_{2} \mathrm{O}$ emission. The use of microbial preparations for pre-seeding bacterization of seeds optimizes the course of biological nitrogen transformation process - through the enhancement of nitrogen fixation activity and reduction of gaseous nitrogen losses (with the exception of Biogran use on potatoes in the year of manure application). Introduction with manure of a large number of microorganisms to the soil offsets the positive effect of biopreparations use. Yield records and estimation of grain output per hectare within the crop rotation cycle indicates the practicability of combined application of manure and microbial preparations (excluding the year of direct effect of organic fertilizer) in organic agriculture.

Key words: organic agriculture, microbial preparations, nitrogen fixation, $\mathrm{N}_{2} \mathrm{O}$ emission, potato, barley, pea, wheat.

Nowadays we observe an active transition of the Ukrainian agricultural sector towards the sustainable and environmentally safe agriculture, including organic production. Thus, at the beginning of 2003 only 31 farms in Ukraine were registered as "organic", while in 2013 their number was already 175, with the 393.4 thousand hectares of total certified organic agricultural land [1].

The question of the effectiveness of organic agriculture is reflected in the studies of local scientists and experts: S. S. Antonets [2], V. M. Pysarenko [3], M. K. Shykulin [4], and others. At the same time, many issues related to the improvement of the efficiency of organic products manufacture remain unstudied.

The list of factors that influence crops productivity in organic agriculture is limited due to high legislation requirements on hygienic purity of products. This stipulates the search for agricultural practices that will contribute to the op- timization of plant root nutrition and crop production processes. The methods used for regulation of microbiological activity in agrocoenoses may be used as the basis for given approach. Manure is considered to be the one of the most important factors influencing the formation of soil microorganisms and the processes they execute. Manure introduces a huge number of microorganisms into the soil, and as V. V. Dokuchaev have said at the end of the nineteenth century: "Of course, the bacteria are introduced to the soil with manure, and their value is probably not less than in fertilizers" [5]. Microbial preparations are also a powerful factor of optimization of microorganisms' composition and biological processes in the soil.

In this regard, the objective of the given work is to study the orientation of individual biological processes in agrocenoses under the use of manure and microbial preparations.

Materials and methods. The study was 
conducted during 2012-2015 in the stationary field experiment of the Institute of Agricultural Microbiology and Agroindustrial Manufacture NAAS, on leached black soils $\left(\mathrm{pH}_{\text {salt }}-5.30\right.$; humus content - 2.12; easily hydrolized nitrogen $-95.2 \mathrm{mg} / \mathrm{kg}$; phosphorus - $226 \mathrm{mg} / \mathrm{kg}$; exchange potassium - $108 \mathrm{mg} / \mathrm{kg}$ ). The following short crop rotational system was used in the experiment: potato (variety Belaroza) / spring barley (variety Gonar) / pea (variety Deviz) / winter wheat (variety Sonechko).

The impact of $40 \mathrm{t} / \mathrm{ha}$ of cattle manure and microbial preparations authorized for use in organic production was tested as the crop fertilization agents. The following preparations were used for pre-seeding treatment: Biogran (microbial agent Azospirillum brasilense) was used for potatoes, Microhumin (microbial agent Azospirillum brasilense) - for spring barley, Rhizohumin (microbial agent Rhizobium leguminosarum) - for pea and Polymyxobacterin (microbial agent Paenibacillus polymyxa) — for winter wheat [6].

The potential activity of nitrogen fixation processes [7] and biological denitrification in the rhizosphere soil of plants was determined in dynamics using the acetylene method [8]. The activity of symbiotic nitrogen fixation in the root nodules of pea was determined using the acetylene method [9]. The crops yield was measured and used for estimation of grain output per hectare within the crop rotation cycle to generalize the effect of the investigated factors on crops productivity.

The statistical processing of the obtained results was performed using the analysis of variance [10] and software package Microsoft Office Excel 2007.

Results and discussion. The study of the potential nitrogen fixation activity in the rhizosphere soil of potato plants indicated the significant increases of indices in variants with pplication of microbial preparation Biogran (Table 1).

However, the activity of the process increases at a greater extent with the use of $40 \mathrm{t} / \mathrm{ha}$ of cattle manure. Application of Biogran combined with the organic background had not changed the nitrogen fixation activity. These relations were confirmed by the following years results. Such peculiarity, in our opinion, is explained by the fact that a large number of microorganisms, including these that fix atmospheric nitrogen, is introduced to the soil with
Table 1. The effect of organic fertilizer and bacterization on the potential nitrogenase activity of rhizosphere soil of potato plants, 2015

\begin{tabular}{|l|c|c|c|}
\hline \multirow{2}{*}{$\begin{array}{l}\text { Variants of } \\
\text { experiment }\end{array}$} & \multicolumn{3}{|c|}{$\begin{array}{c}\text { Nitrogenase activity, } \\
\text { nmol } \mathrm{C}_{2} \mathrm{H}_{4} / g \text { of dry soil per hour }\end{array}$} \\
\cline { 2 - 4 } & $\begin{array}{c}\text { Start of } \\
\text { budding } \\
\text { stage }\end{array}$ & $\begin{array}{c}\text { Flower- } \\
\text { ing stage }\end{array}$ & $\begin{array}{c}\text { Top } \\
\text { necrosis } \\
\text { stage }\end{array}$ \\
\hline \multicolumn{3}{|c|}{ without bacterization } \\
\hline $\begin{array}{l}\text { Control, } \\
\text { without } \\
\text { fertilizers }\end{array}$ & 10.4 & 11.5 & 4.2 \\
\hline $\begin{array}{l}\text { Cattle manu- } \\
\text { re, 40 t/ha }\end{array}$ & 40.1 & 52.4 & 12.2 \\
\hline \multicolumn{2}{|c|}{ with Biohran } \\
\hline $\begin{array}{l}\text { Without } \\
\text { fertilizers }\end{array}$ & 20.5 & 29.3 & 11.9 \\
\hline $\begin{array}{l}\text { Cattle manu- } \\
\text { re, 40 t/ha }\end{array}$ & 40.5 & 53.5 & 15.1 \\
\hline \multicolumn{1}{|c|}{ LSD } & 2.2 & 3.0 & 2.6 \\
\hline
\end{tabular}

manure. In other terms the manure application ensures non-specific soil bacterization. Under these conditions, microorganisms introduced with the biological preparation into the agrocenosis undergo strong competition that on a greater extend reduces their effectiveness.

The analysis of nitrogen activity indicators highlights the environmentally favourability of both manure and microbial preparation application, since nitrogen fixation does not occur under the excess of mineral nitrogen compounds, thus supporting the expediency of fertilizers use [11].

At the same time, a high level of biological denitrification upon the introduction of $40 \mathrm{t} / \mathrm{ha}$ manure was observed (Table 2). Since the simultaneous high values of the nitrogen fixation activity and $\mathrm{N}_{2} \mathrm{O}$ emissions in the ecological niche contradict the logic regarding the conditions of their flow, we believe that the introduction of manure in the soil forms microzones, where certain processes are dominated, including the opposite ones. The obtained results had also proved the need the classical approach to manure preparation prior to its use through the preliminary composting, which allows stabilization of the population of microorganism in the substrate and completion of the nitrogen and carbon transformation processes. 
Table 2. The effect of organic fertilizer and bacterization on the potential $\mathrm{N}_{2} \mathrm{O}$ emission of rhizosphere soil of potato plants, 2015

\begin{tabular}{|c|c|c|c|}
\hline \multirow[b]{2}{*}{$\begin{array}{l}\text { Variants of } \\
\text { experiment }\end{array}$} & \multicolumn{3}{|c|}{ nmol $\mathrm{N}_{2} \mathrm{O} / \mathrm{g}$ of dry soil per $24 \mathrm{~h}$} \\
\hline & $\begin{array}{c}\text { Start of } \\
\text { budding } \\
\text { stage }\end{array}$ & $\begin{array}{l}\text { Flower- } \\
\text { ing stage }\end{array}$ & $\begin{array}{c}\text { Top } \\
\text { necrosis } \\
\text { stage }\end{array}$ \\
\hline \multicolumn{4}{|c|}{ without bacterization } \\
\hline $\begin{array}{l}\text { Control, } \\
\text { without } \\
\text { fertilizers }\end{array}$ & 11.5 & 6.9 & 4.2 \\
\hline $\begin{array}{l}\text { Cattle manu- } \\
\text { re, } 40 \mathrm{t} / \mathrm{ha}\end{array}$ & 40.1 & 29.0 & 12.2 \\
\hline \multicolumn{4}{|c|}{ with Biohran } \\
\hline $\begin{array}{l}\text { Without } \\
\text { fertilizers }\end{array}$ & 10.0 & 6.3 & 3.5 \\
\hline $\begin{array}{l}\text { Cattle manu- } \\
\text { re, } 40 \mathrm{t} / \mathrm{ha}\end{array}$ & 40.5 & 30.5 & 13.1 \\
\hline $\mathrm{LSD}_{05}$ & 3.3 & 2.6 & 2.1 \\
\hline
\end{tabular}

As is indicted in Table 2 the use of Biogran on the background of manure application had reduced the intensity of nitrous oxide emissions.

Determination of the orientation of nitrogen fixation process in the root zone of barley plants (next crop in the crop rotation), had revealed the increase of nitrogen fixation activity on the manure after-effect background (Table 3 ).

The use of Microhumin for pre-seeding bacterization of barley had also promoted the significant stimulation of nitrogen fixation activity. In contrast to the conditions prevailing in the first year of manure use, the after-effect of this organic fertilizer created a perfect background for the use of a microbial preparation in crop growing technology, as the conditions developed during the first year of manure aftereffect in soil are very favourable for the effective microbial preparation performance.

This conclusion is confirmed by the determination of the potential emission of nitrous oxide from rhizosphere soil of barley plants. In particular, the use of Microhumin had reduced the activity of biological denitrification both in control and on organic fertilizers background (Table 4). The reduction of gaseous losses of nitrogen is most likely due to a decrease in the content of nitrates in the soil caused by plant bacterization. Bacterized plants require a greater number of mineral nitrogen compounds, includ-
Table 3. The potential nitrogenase activity of rhizosphere soil of barley plants under the first year of manure after-effect and application of Microhumin, 2015

\begin{tabular}{|l|c|c|c|}
\hline \multirow{2}{*}{$\begin{array}{l}\text { Variants of } \\
\text { experiment }\end{array}$} & \multicolumn{3}{|c|}{$\begin{array}{c}\text { Nitrogenase activity, } \\
n m o l \mathrm{C}_{2} \mathrm{H}_{4} / g \text { of dry soil per hour }\end{array}$} \\
\cline { 2 - 4 } & $\begin{array}{c}\text { Tillering } \\
\text { stage }\end{array}$ & $\begin{array}{c}\text { Booting } \\
\text { stage }\end{array}$ & $\begin{array}{c}\text { Milky- } \\
\text { wax ripe- } \\
\text { ness }\end{array}$ \\
\hline without bacterization \\
\hline $\begin{array}{l}\text { Control, } \\
\text { without } \\
\text { fertilizers }\end{array}$ & 2.0 & 1.9 & 3.0 \\
\hline $\begin{array}{l}\text { After effect } \\
\text { of cattle ma- } \\
\text { nure, 40 t/ha }\end{array}$ & 2.7 & 3.9 & 5.8 \\
\hline \multicolumn{2}{|c|}{ with Microhumin } & \\
\hline $\begin{array}{l}\text { Without } \\
\text { fertilizers }\end{array}$ & 4.3 & 3.5 & 3.6 \\
\hline $\begin{array}{l}\text { After-effect } \\
\text { of cattle ma- } \\
\text { nure, 40 t/ha }\end{array}$ & 7.5 & 4.4 & 7.4 \\
\hline \multicolumn{1}{|c|}{ LSD }
\end{tabular}

Table 4. The potential emissions of $\mathrm{N}_{2} \mathrm{O}$ from rhizosphere soil of barley plants under the first year of after-effect of manure and use of Microhumin, 2015

\begin{tabular}{|c|c|c|c|}
\hline \multirow[b]{2}{*}{$\begin{array}{l}\text { Variants of } \\
\text { experiment }\end{array}$} & \multicolumn{3}{|c|}{ nmol $\mathrm{N}_{2} \mathrm{O} / \mathrm{g}$ of dry soil per $24 \mathrm{~h}$} \\
\hline & $\begin{array}{c}\text { Tillering } \\
\text { stage }\end{array}$ & $\begin{array}{c}\text { Booting } \\
\text { stage }\end{array}$ & $\begin{array}{c}\text { Milky- } \\
\text { wax ripe- } \\
\text { ness }\end{array}$ \\
\hline \multicolumn{4}{|c|}{ without bacterization } \\
\hline $\begin{array}{l}\text { Control, } \\
\text { without } \\
\text { fertilizers }\end{array}$ & 6.4 & 5.3 & 5.8 \\
\hline $\begin{array}{l}\text { After effect } \\
\text { of cattle ma- } \\
\text { nure, } 40 \mathrm{t} / \mathrm{ha}\end{array}$ & 13.0 & 12.1 & 12.0 \\
\hline \multicolumn{4}{|c|}{ with Microhumin } \\
\hline $\begin{array}{l}\text { Without } \\
\text { fertilizers }\end{array}$ & 4.2 & 3.6 & 5.3 \\
\hline $\begin{array}{l}\text { After-effect } \\
\text { of cattle ma- } \\
\text { nure, } 40 \mathrm{t} / \mathrm{ha}\end{array}$ & 10.8 & 10.3 & 11.7 \\
\hline $\mathrm{LSD}_{05}$ & 1.2 & 1.0 & 1.2 \\
\hline
\end{tabular}


ing nitrates, which are the substrate basis for the biological denitrification process to provide a constructive metabolism. As a reflection of this, we observe changes in the intensity of $\mathrm{N}_{2} \mathrm{O}$ emission.

Determination of the symbiotic nitrogen fixation activity in pea agrocenoses had shown the process intensification under the use of Rhizohumin (Table 5). The after-effect of manure had a positive effect on the nitrogen fixation activity, while introduction of the biological preparation had resulted in minor changes of the studied parameters.

Table 5. The symbiotic nitrogen fixation activity in pea agrocenoses under the aftereffect of manure and application of Rhizohumin, 2015

\begin{tabular}{|l|c|c|c|}
\hline \multirow{2}{*}{$\begin{array}{l}\text { Variants of } \\
\text { experiment }\end{array}$} & \multicolumn{3}{|c|}{$\begin{array}{c}\text { Nitrogenase activity, } \\
\text { nmol } \mathrm{C}_{2} \mathrm{H}_{4} / \text { plant per hour }\end{array}$} \\
\cline { 2 - 4 } stage & $\begin{array}{c}\text { Budding } \\
\text { stage }\end{array}$ & $\begin{array}{c}\text { Pod for- } \\
\text { mation } \\
\text { stage }\end{array}$ \\
\hline \multicolumn{3}{|c|}{ without bacterization } \\
\hline $\begin{array}{l}\text { Control, } \\
\text { without } \\
\text { fertilizers }\end{array}$ & 7.1 & 10.8 & 10.6 \\
\hline $\begin{array}{l}\text { After effect } \\
\text { of cattle ma- } \\
\text { nure, 40 t/ha }\end{array}$ & 11.3 & 16.8 & 13.4 \\
\hline \multicolumn{1}{|c|}{ bacterization with Rhizohumin } \\
\hline $\begin{array}{l}\text { Without } \\
\text { fertilizers }\end{array}$ & 13.2 & 13.1 & 12.8 \\
\hline $\begin{array}{l}\text { After-effect } \\
\text { of cattle ma- } \\
\text { nure, 40 t/ha }\end{array}$ & 12.1 & 16.2 & 13.8 \\
\hline \multicolumn{1}{|c|}{ LSD } & 2.4 & 2.2 & 1.6 \\
\hline
\end{tabular}

At the same time, Rhizohumin application had positively changed the process of biological denitrification in the rhizosphere soil of pea plants (Table 6), ensuring the reduction of $\mathrm{N}_{2} \mathrm{O}$ emission on both studied backgrounds.

An overall low level of the potential nitrogen fixation activity was observed in the rhizosphere soil of winter wheat plants while the after-effect of manure in general had ensured the growth of studied parameters (Table 7). Microbial preparation Polymyxobacterin had also influenced to some extent on the process inten-
Table 6. The potential emissions of $\mathrm{N}_{2} \mathrm{O}$ from rhizosphere soil of pea plants under the second year of after-effect of manure and application of Rhizohumin, 2015

\begin{tabular}{|c|c|c|c|}
\hline \multirow[b]{2}{*}{$\begin{array}{l}\text { Variants of } \\
\text { experiment }\end{array}$} & \multicolumn{3}{|c|}{ nmol $\mathrm{N}_{2} \mathrm{O} / \mathrm{g}$ of dry soil per $24 \mathrm{~h}$} \\
\hline & $\begin{array}{l}\text { Booting } \\
\text { stage }\end{array}$ & $\begin{array}{l}\text { Budding } \\
\text { stage }\end{array}$ & $\begin{array}{l}\text { Pod for- } \\
\text { mation } \\
\text { stage }\end{array}$ \\
\hline \multicolumn{4}{|c|}{ without bacterization } \\
\hline $\begin{array}{l}\text { Control, } \\
\text { without } \\
\text { fertilizers } \\
\end{array}$ & 11.1 & 8.8 & 14.3 \\
\hline $\begin{array}{l}\text { After effect } \\
\text { of cattle ma- } \\
\text { nure, } 40 \mathrm{t} / \mathrm{ha}\end{array}$ & 17.9 & 20.6 & 30.4 \\
\hline \multicolumn{4}{|c|}{ with Rhizohumin } \\
\hline $\begin{array}{l}\text { Without } \\
\text { fertilizers }\end{array}$ & 7.1 & 7.0 & 10.9 \\
\hline $\begin{array}{l}\text { After-effect } \\
\text { of cattle ma- } \\
\text { nure, } 40 \mathrm{t} / \mathrm{ha}\end{array}$ & 14.0 & 20.5 & 26.9 \\
\hline $\mathrm{LSD}_{05}$ & 1.9 & 1.4 & 2.3 \\
\hline
\end{tabular}

Table 7. The effect of bacterization and after-effect of organic fertilizer on the potential nitrogen fixation activity of rhizosphere soil of winter wheat plants, 2015

\begin{tabular}{|l|c|c|c|}
\hline \multirow{2}{*}{$\begin{array}{l}\text { Variants of } \\
\text { experiment }\end{array}$} & $\begin{array}{c}\text { Tillering } \\
\text { stage }\end{array}$ & $\begin{array}{c}\text { Booting } \\
\text { stage }\end{array}$ & $\begin{array}{c}\text { Milky- } \\
\text { wax ripe- } \\
\text { ness }\end{array}$ \\
\cline { 2 - 4 } & \multicolumn{3}{|c|}{ without bacterization } \\
\hline $\begin{array}{l}\text { Control, } \\
\text { without } \\
\text { fertilizers }\end{array}$ & 0.2 & 2.2 & 4.5 \\
\hline $\begin{array}{l}\text { After effect } \\
\text { of cattle ma- } \\
\text { nure (third } \\
\text { year), 40 t/ha }\end{array}$ & 0.4 & 2.7 & 5.6 \\
\hline \multicolumn{1}{|c|}{ bacterization with Polymyxobacterin soil per hour } \\
\hline $\begin{array}{l}\text { Without } \\
\text { fertilizers }\end{array}$ & 0.2 & 2.3 & 6.0 \\
\hline $\begin{array}{l}\text { After-effect } \\
\text { of cattle ma- } \\
\text { nure (third } \\
\text { year), 40 t/ha }\end{array}$ & 0.2 & 2.2 & 7.1 \\
\hline \multicolumn{1}{|c|}{ LSD 05}
\end{tabular} \mid \begin{tabular}{c}
$|c|$ \\
\hline
\end{tabular}


sity (not in direct way but through the changes in plants development, as it is based on phosphate-mobilizing bacteria Paenibacillus polymyxa KB, known as a producer of phytohormones).

The gaseous nitrogen losses under the third year of manure after-effect were significantly higher comparing to the control values (Table 8), especially during the tillering stage of wheta growth. However, Polymyxobacterin reduces biological denitrification activity in the root zone of plants, which is probably due to the intensification of the growth and development of bacterized plants and the greater absorption of mineral nitrogen compounds by plants.

Table 8. The effect of fertilizers and bacterization on the potential biological denitrification activity of rhizosphere soil of winter wheat, 2015

\begin{tabular}{|c|c|c|c|}
\hline \multirow[b]{2}{*}{$\begin{array}{l}\text { Variants of } \\
\text { experiment }\end{array}$} & \multicolumn{3}{|c|}{ nmol $\mathrm{N}_{2} \mathrm{O} / \mathrm{g}$ of soil per hour } \\
\hline & $\begin{array}{c}\text { Tillering } \\
\text { stage }\end{array}$ & $\begin{array}{c}\text { Booting } \\
\text { stage }\end{array}$ & $\begin{array}{c}\text { Milky- } \\
\text { wax ripe- } \\
\text { ness }\end{array}$ \\
\hline \multicolumn{4}{|c|}{ without bacterization } \\
\hline $\begin{array}{l}\text { Control, } \\
\text { without } \\
\text { fertilizers }\end{array}$ & 9.7 & 7.5 & 5.4 \\
\hline $\begin{array}{l}\text { After effect } \\
\text { of cattle ma- } \\
\text { nure (third } \\
\text { year), } 40 \mathrm{t} / \mathrm{ha}\end{array}$ & 18.1 & 11.1 & 5.4 \\
\hline \multicolumn{4}{|c|}{ bacterization with Polymyxobacterin } \\
\hline $\begin{array}{l}\text { Without } \\
\text { fertilizers }\end{array}$ & 7.2 & 6.9 & 4.0 \\
\hline $\begin{array}{l}\text { After-effect } \\
\text { of cattle ma- } \\
\text { nure (third } \\
\text { year), } 40 \mathrm{t} / \mathrm{ha}\end{array}$ & 13.7 & 9.7 & 4.7 \\
\hline $\mathrm{LSD}_{05}$ & 1.0 & 1.5 & 0.8 \\
\hline
\end{tabular}

Given peculiarities of the studied processes were observed during all research years.

Analysis of crop yields in crop rotation had indicated a high fertilization potential of cattle manure (Table 9). The direct effect of manure on potato yields provided an average of $73 \%$ by all studied parameters. Application of Biogran upon the control background had ensure additional $9 \%$ oy crop production, while was not
Table 9. Crop yields upon the application of manure and biological preparations (average over 5 years), $t / h a$

\begin{tabular}{|l|c|c|}
\hline \multicolumn{1}{|c|}{$\begin{array}{c}\text { Variants of } \\
\text { experiment }\end{array}$} & $\begin{array}{c}\text { Without } \\
\text { bacterization }\end{array}$ & $\begin{array}{c}\text { With } \\
\text { bacterization }\end{array}$ \\
\hline \multicolumn{3}{|c|}{ Potato } \\
\hline $\begin{array}{l}\text { Without } \\
\text { fertilizers }\end{array}$ & 15.6 & 17.0 \\
\hline $\begin{array}{l}\text { Cattle manure, } \\
40 \text { t/ha }\end{array}$ & 27.1 & 27.8 \\
\hline \multicolumn{2}{|c|}{1.2} \\
\hline
\end{tabular}

\begin{tabular}{|l|c|c|}
\hline \multicolumn{3}{|c|}{ Spring barley } \\
\hline $\begin{array}{l}\text { Without } \\
\text { fertilizers }\end{array}$ & 2.4 & 2.6 \\
\hline $\begin{array}{l}\text { Cattle manure, } \\
40 \text { t/ha (after- } \\
\text { effect of the } \\
\text { first year) }\end{array}$ & 2.9 & 3.3 \\
\hline \multicolumn{2}{|c|}{ LSD $_{05}$} & Pea \\
\hline \multicolumn{2}{|c|}{0.2} \\
\hline $\begin{array}{l}\text { Without } \\
\text { fertilizers }\end{array}$ & 2.2 & 2.5 \\
\hline $\begin{array}{l}\text { Cattle manure, } \\
40 \text { t/ha (after- } \\
\text { effect of the } \\
\text { second year) }\end{array}$ & 2.5 & 2.8 \\
\hline \multicolumn{1}{|c|}{ LSD $_{05}$} & LSD \\
\hline \multicolumn{2}{|c|}{ Winter wheat } \\
\hline $\begin{array}{l}\text { Without fertiliz- } \\
\text { ers }\end{array}$ & 4.9 & 5.5 \\
\hline $\begin{array}{l}\text { Cattle manure, } \\
40 \text { t/ha (after- } \\
\text { effect of the } \\
\text { third year) }\end{array}$ & 6.2 & 6.5 \\
\hline \multicolumn{2}{|c|}{0.3} \\
\hline
\end{tabular}

effective upon its use on the manure background. Thus, indicating no need in the use of biological preparations during the same year of manure introduction.

The after-effect of manure on the first year had improved barley yield by providing extra $0.5 \mathrm{t} / \mathrm{ha}$ of grain. The interaction of the organic background with Microhumin was proved to be effective, ensuring the highest yield of $3.3 \mathrm{t} / \mathrm{ha}$.

Additional $0.3 \mathrm{t} / \mathrm{ha}$ of peas were obtained upon the second-year after-effect of cattle ma- 
nure. The same figures were obtained also in variants with Rhizohumin, providing extra $0.6 \mathrm{t} / \mathrm{ha}$ of peas upon the use of microbial preparation on the organic background.

The peas are known to be one of the best pre-crops for winter wheat. In our experiment, the cultivation of wheat after pea had yielded $4.9 \mathrm{t} / \mathrm{ha}$ of grain. The third-year after-effect of manure had contributed to obtaining additional $1.3 \mathrm{t} / \mathrm{ha}$. The application of the microbial preparation had increased the yield by $0.6 \mathrm{t} / \mathrm{ha}$ comparing to the control background and by $1.6 \mathrm{t} / \mathrm{ha}$ comparing to the manure application (Table 9).

In order to ensure the objectivity of the conclusions, we have transformed the yield in the grain units since the different crops were cultivated in the studied crop rotation, whose products are difficult to compare.

The calculations shown in table 10 indicate that the organic fertilizers (cattle manure, $40 \mathrm{t} / \mathrm{ha}$ ) had provided an increase in grain units in the range of $1.3 \mathrm{t} / \mathrm{ha}$ per crop rotation area. Application of the biological preparations capable of optimization of the biological processes course in agrocenoses had ensured extra $0.4 \mathrm{t} / \mathrm{ha}$ of grain units. The combination of biological preparations with organic background had provided additional 0.3 tons of grain units per hectare of crop rotation area.

Thus, the study performed had shown that the use of $40 \mathrm{t} / \mathrm{ha}$ of cattle manure ensures a significant increase of the nitrogen fixation activity in the root zone of plants. At the same time, the introduction manure is accompanied with the significant losses of gaseous nitrogen compounds. The use of microbial preparations may meaningfully optimize the course of bio- logical nitrogen transformation processes in agrocenoses. At the same time, in the year of manure introduction, the effectiveness of preseeding bacterization is levelled, which should be taken into the account when designing a fertilization system in the organic production system.

1. Томашевська О. А. Органічне виробництво в світі: реалії та перспективи / О. А. Томашевська // Інноваційна економіка. - 2013. № 6. - С. 161-164.

2. Антонец С. Поле без плуга - по велению души / С. Антонец; записал П. Коротич // Надежда планеты. — 2009. — № 6. - С. 8-11.

3. Писаренко В. М. Основні напрями інтегрованого захисту рослин в умовах органічного землеробства / В. М. Писаренко // Вісник Полтавської державної аграрної академії. - 2008. № 4. - C. 14-18.

4. Шикула М. К. Вплив мінімального обробітку на родючість чорнозему / М. К. Шикула, О.В. Демиденко // Вісник аграрної науки. 2004. - № 8. - С. 18-23.

5. Докучаев В. В. К вопросу об открытии при русских университетах кафедр почвоведения и учение о микроорганизмах / В.В.Докучаев // Избранные сочинения. - М. : Гос. издательство с.-х. литературы, 1948. - Т. 2. - С. 290-318.

6. Мікробні препарати у землеробстві. Теорія і практика: монографія / [Волкогон В. В., Надкернична О. В., Ковалевська Т. М. та ін.] ; за ред. В. В. Волкогона. - К. : Аграрна наука, 2006. - 312 c.

7. Умаров М. М. Ацетиленовый метод изучения азотфиксации в почвенно-микробиологических исследованиях / М. М. Умаров // Почвоведение. - 1976. - № 11. - С. 119-123.

Table 10. The effect of organic fertilizer and biological preparations on the yield of grain units

\begin{tabular}{|l|c|c|c|c|c|}
\hline \multirow{2}{*}{$\begin{array}{c}\text { Variants of } \\
\text { experiment }\end{array}$} & \multicolumn{6}{|c|}{$\begin{array}{c}\text { Grain units by crops of crop rotation } \\
\text { (average for one of five years), t/ha }\end{array}$} & $\begin{array}{c}\text { Grain units (average for } \\
\text { one of five years), } \\
\text { t/ha of crop rotation area }\end{array}$ \\
\cline { 2 - 6 } & potato & barley & pea & wheat & \\
\hline \multicolumn{7}{|c|}{ without bacterization } \\
\hline Without fertilizer & 3.9 & 3.0 & 2.6 & 5.2 & 3.7 \\
\hline 40 t/ha of manure & 6.8 & 3.6 & 3.0 & 6.6 & 5.0 \\
\hline \multicolumn{7}{|c|}{ with bacterization } \\
\hline Without fertilizer & 4.3 & 3.3 & 3.0 & 5.6 & 4.1 \\
\hline 40 t/ha of manure & 6.9 & 4.1 & 3.4 & 6.8 & 5.3 \\
\hline
\end{tabular}


8. Методы почвенной микробиологии и биохимии / [И. В. Асеева, И. П. Бабьева, Б. А. Бызов и др.] ; под ред. Д. Г. Звягинцева. - М. : МГУ, 1991. - 304 c.

9. Експериментальна грунтова мікробіологія / [В. В. Волкогон, О.В.Надкернична, Л. М. Токмакова та ін.]; за ред. В. В. Волкогона. - К. : Аграрна наука, 2010. - 464 с.

10. Доспехов Б. А. Методика полевого опыта

\section{СПРЯМОВАНІСТЬ ПРОЦЕСІВ БІОЛО- ГІЧНОЇ ТРАНСФОРМАЦЇ̈ АЗОТУ В ІРУНТІ ЗА ОРГАНІЧНОГО ВИРОБНИЦТВА СІЛЬСЬКОГОСПО- ДАРСЬКОї ПРОДУКЦІї}

\author{
В. В. Волкогон, А. М. Москаленко, \\ С. Б. Дімова, М. А. Журба, \\ К. І. Волкогон, Л. М. Токмакова, \\ Н. П. Штанько, Н. В. Луценко
}

Інститут сільськогосподарської мікробіології та агропромислового виробництва НААН, м. Чернігів

У польовому стачіонарному досліді на чорноземі вилуженому визначали вплив прямої дії і післядії 40 m/га гною ВРХ на спрямованість прочесів азотфіксації та біологічної денітрифікації в кореневій зоні рослин картоплі, ячменю ярого, гороху і пшениці озимоі за їх вирощування в сівозміні. Застосування гною сприяє суттевому зростанню активності азотфіксачії $i$ водночас забезпечуе високий рівень емісії $\mathrm{N}_{2} \mathrm{O}$. Використання в технологіях вирощування культур мікробних препаратів для передпосівної бактеризачіі насіннєвого матеріалу оптимізує перебіг процесів біологічної трансформачї̈ азоту зростає активність азотфіксаиії $i$ зменшуються газоподібні втрати елементу. Винятком $\epsilon$ застосування препарату Біограну для картоплі в рік внесення гною. Надходження до трунту великої кількості мікроорганізмів з гноєм нівелює позитивний ефект біопрепарату. Облік урожаю та розрахунок виходу зернових одиниць з гектара сівозмінної площі свідчить про доиільність поєднання гною та мікробних препаратів (за виключенням року прямої дії органічного добрива) у системі органічного виробництва.

Ключові слова: органічне виробництво сільськогосподарської продукиії, мікробні препарати, азотфіксація, емісія $\mathrm{N}_{2} \mathrm{O}$, картопля, ячмінь, горох, пшениця. с основами статистической обработки результатов исследований / Б. А. Доспехов - [5-е изд.]. М. : Агропромиздат, 1985. - $351 \mathrm{c.}$

11. Визначення фізіологічно (екологічно) доцільних доз мінерального азоту в технологіях вирощування сільськогосподарських культур (науково-методичні рекомендації) / [І.В.Гриник, А. С. Заришняк, В. В. Волкогон та ін.]. - К., 2010. $-35 \mathrm{c}$.

\section{НАПРАВЛЕННОСТЬ ПРОЦЕССОВ БИОЛОГИЧЕСКОЙ ТРАНСФОРМА- ЦИИ АЗОТА В ПОЧВЕ ПРИ ОРГАНИ- ЧЕСКОМ ПРОИЗВОДСТВЕ СЕЛЬСКО- ХОЗЯЙСТВЕННОЙ ПРОДУКЦИИ}

\author{
В. В. Волкогон, А. М. Москаленко, \\ С. Б. Димова, М. А. Журба, \\ Е. И. Волкогон, Л. Н. Токмакова, \\ Н. П. Штанько, Н. В. Луценко
}

Институт сельскохозяйственной микробиологии и агропромышленного производства НААН, г. Чернигов

В полевом стационарном опыте на чернозёме выщелоченном изучали влияние прямого действия и последействия навоза ВРХ на направленность процессов азотфиксачии и биологической денитрификации в корневой зоне растений картофеля, ячменя ярового, гороха и пшенищь озимой при их выращивании в севообороте. Применение навоза способствует существенному возрастанию активности азотфиксации и в то же время обеспечивает высокий уровень эмиссии $\mathrm{N}_{2} \mathrm{O}$. Использование в технологиях выращивания культур микробных препаратов для предпосевной обработки посевного материала оптимизирует направленность прочессов биологической трансформаџии азота - возрастает активность азотфиксаџии и уменьшаются газообразные потери элемента. Исключением является применение препарата Биограна для картофеля в год внесения навоза. Поступление в почву вместе с навозом огромного количества микроорганизмов нивелирует положительный эффект биопрепарата. Учёт урожая и расчёт выхода зерновых единии с гектара севооборотной площади свидетельствует о целесообразности сочетания навоза и микробных препаратов (исключением является год прямого действия органического удобрения) в системе органического производства.

Ключевые слова: органическое производство сельскохозяйственной продукиии, микробные препаратьи, азотфиксаиия, эмиссия $\mathrm{N}_{2} \mathrm{O}$, картофель, ячмень, горох, пшеница. 